\title{
Chloramphenicol in royal jelly: analytical aspects and occurrence in Italian imports*
}

\author{
Silvano CAlvarese, Anna Francesca ForTI, Giampiero ScORTICHINI, \\ Gianfranco DILETTI \\ Istituto Zooprofilattico Sperimentale dell'Abruzzo e Molise "G. Caporale”, Via Campo Boario, \\ 64100 Teramo, Italy
}

Received 18 May 2005 - Revised 31 January 2006 - Accepted 31 January 2006

\begin{abstract}
Chloramphenicol (CAP) residues were determined in 35 samples of royal jelly. Fourteen samples were collected by Veterinary Border Inspection officials in Milan and Turin and 21 were submitted by private importers to confirm the quality of their product. Liquid chromatography-tandem mass spectrometry (LC-MS/MS) was used for the identification and determination of CAP, according to the isotope dilution approach for the analysis of royal jelly. The presence of chloramphenicol was detected in 29 out of 35 tested samples at concentrations ranging from $0.6 \mu \mathrm{g} / \mathrm{kg}$ to $28 \mu \mathrm{g} / \mathrm{kg}$, with an average content of $6.1 \mu \mathrm{g} / \mathrm{kg}$.
\end{abstract}

royal jelly / chloramphenicol / residue / antibiotics / liquid chromatography-tandem mass spectrometry

\section{INTRODUCTION}

Royal jelly is commonly consumed for its nutritional properties and is produced at low costs in some countries, exceeding a total of 1 million $\mathrm{kg}$ in China in 2002 (Chen-Sheng et al., 2002). Chloramphenicol (CAP) is a broad spectrum antibiotic widely used in the treatment of several infectious diseases (Allen, 1985).

Human exposure to chloramphenicol could cause aplastic anaemia and its genotoxicity has been demonstrated in several in vivo and in vitro test systems (WHO, 1994, 1995). Consequently, its use in food-producing animals and animal feed products is prohibited in many countries such as the United States (USA), Canada, Australia and European Union (EU) member states (Mottier et al., 2003). However, few reports are available in the literature on the number of analyses done on royal jelly and the CAP contamination levels detected in this

Corresponding author: S. Calvarese,

s.calvarese@izs.it

* Manuscript editor: Stefan Fuchs product. From 2002 to present, four cases of the presence of CAP in royal jelly have been reported by the "Annual Report on the Functioning of the RASFF" (RASFF, 2002-2004; FSA, 2002).

A further problem is represented by the analytical methods. While many confirmatory methods are described for the determination of CAP in several food matrices (Hormazabal and Yndestad, 2001; Verzegnassi et al., 2003; Gantverg et al., 2003; Ramos et al., 2003; Mottier et al., 2003; Bogusz et al., 2004), nothing has been published on methods for its detection in royal jelly. The present work is aimed at describing a method for the determination of CAP by LC-MS/MS to verify the quality of royal jelly in samples imported into Italy.

\section{MATERIALS AND METHODS}

\subsection{Sampling}

Between February 2003 and May 2004, 35 royal jelly samples were tested; 14 of them were collected 
by the Veterinary Border Inspection Post officials at the airports of Milan Malpensa and Turin Caselle and 21 were submitted by private importers wanting to confirm the quality of the imported product.

\subsection{Analysis}

\subsubsection{Reagents}

All reagents and solvents were of analytical or HPLC grade quality and were supplied by J.T. Baker (Deventer, Holland) and Carlo Erba (Milan, Italy). Ultrapure water was obtained by Milli-Q system Millipore (Bedford, MA, USA). The octadecyl $\left(\mathrm{C}_{18}\right)$ solid-phase extraction (SPE) cartridges $(500 \mathrm{mg} / 3 \mathrm{~mL})$ were from J.T. Baker. The phosphate buffer solution (PBS) at $\mathrm{pH} 7.8$ was prepared by mixing a solution of $\mathrm{KH}_{2} \mathrm{PO}_{4} \cdot \mathrm{H}_{2} \mathrm{O}(0.1 \mathrm{M})$ and one of $\mathrm{Na}_{2} \mathrm{HPO}_{4} \cdot 2 \mathrm{H}_{2} \mathrm{O}(0.1 \mathrm{M})(8.5: 91.5, \mathrm{v} / \mathrm{v})$.

\subsubsection{Standards}

CAP standard was purchased from SigmaAldrich (Milan, Italy) while 5D-CAP, used as an internal standard, was obtained from Cambridge Isotope Laboratories (Andover, MA, USA). CAP and 5D-CAP stock solutions at the concentration of $1.0 \mathrm{mg} / \mathrm{mL}$ were both prepared in methanol and stored at $4{ }^{\circ} \mathrm{C}$.

\subsubsection{Apparatus}

The instrumental analysis was carried out using a LC-MS/MS system consisting of a Series 200 HPLC (Perkin Elmer, Norwalk, CT, USA) coupled to an API 2000 triple quadrupole mass spectrometer (Sciex, Toronto, Canada) equipped with TurboIon Spray ${ }^{T M}$ source. The chromatographic separation was performed on a LUNA ODS (2) $\mathrm{C}_{18} 3 \mu \mathrm{m}$ column $(75 \mathrm{~mm} \times 4.6 \mathrm{~mm}$ i.d.) (Phenomenex, Torrance, CA, USA) by using an isocratic mobile phase of methanol and $5 \mathrm{mM}$ ammonium acetate (60:40, $\mathrm{v} / \mathrm{v})$. The flow rate was set at $0.2 \mathrm{~mL} / \mathrm{min}$, the injection volume at $50 \mu \mathrm{L}$ and the column temperature at $40{ }^{\circ} \mathrm{C}$. The MS detector was operated in the negative ion mode. The capillary voltage was set at $4.5 \mathrm{kV}$ with an orifice potential of $20 \mathrm{~V}$ while the source was heated to $450{ }^{\circ} \mathrm{C}$. Nitrogen was used as a collision gas. The collision energies were optimised separately for the two selected ion transitions of both CAP and 5D-CAP (Tab. I). Data were
Table I. Ion transitions and corresponding collision energies used for CAP quantification.

\begin{tabular}{lcc}
\hline Analyte & $\begin{array}{c}\text { Ion transition } \\
(\mathrm{m} / \mathrm{z})\end{array}$ & $\begin{array}{c}\text { Collision energy } \\
(\mathrm{eV})\end{array}$ \\
\hline CAP & $321-152$ & 22 \\
& $321-121$ & 46 \\
5D-CAP & $326-157$ & 22 \\
& $326-126$ & 46 \\
\hline
\end{tabular}

acquired according to the Multiple Reaction Monitoring (MRM) approach, by selecting two ion transition reactions for both CAP and 5D-CAP (Fig. 1). CAP quantification was accomplished according to the isotope dilution on the most intense ion transition of the analyte.

\subsubsection{Sample preparation}

An aliquot of $10 \mathrm{~g}$ of royal jelly was spiked with $25 \mu \mathrm{L}$ of 5D-CAP at the concentration of $1 \mathrm{mg} / \mathrm{L}$ (corresponding to $2.5 \mu \mathrm{g} / \mathrm{kg}$ ). It was extracted with $50 \mathrm{~mL}$ of a mixture containing dichloromethaneacetone $(1: 1, \mathrm{v} / \mathrm{v})$ in Ultra Turrax. After centrifugation $(5 \mathrm{~min}, 1280 \mathrm{~g}) 5 \mathrm{~mL}$ of supernatant was dried under a stream of nitrogen at $50{ }^{\circ} \mathrm{C}$. The remainder was dissolved in $2.5 \mathrm{~mL}$ of PBS buffer at $\mathrm{pH} 7.8$, thus purified on a $\mathrm{C}_{18}$ column pre-activated with $2.5 \mathrm{~mL}$ of methanol and $5 \mathrm{~mL}$ of water. The cartridge was first washed with $5 \mathrm{~mL}$ of water and then with $5 \mathrm{~mL}$ of petroleum ether. CAP was eluted with $10 \mathrm{~mL}$ of diethyl ether, the eluate was evaporated to dryness in nitrogen flow and the residue was dissolved in $200 \mu \mathrm{L}$ of the LC-MS/MS mobile phase. The chromatograms of a standard solution of CAP, of a negative royal jelly sample and of a naturally incurred sample are shown in Figure 2.

\subsubsection{Method validation}

The validation tests included the analysis of 10 blanks and of 17 spiked samples. Blanks were represented by samples of royal jelly free from CAP and they were used for the evaluation of specificity and limit of detection (LOD). The analytical performance was evaluated by means of samples fortified with CAP at three different concentration levels, $0.3,0.5$ and $1.0 \mu \mathrm{g} / \mathrm{kg}$. 


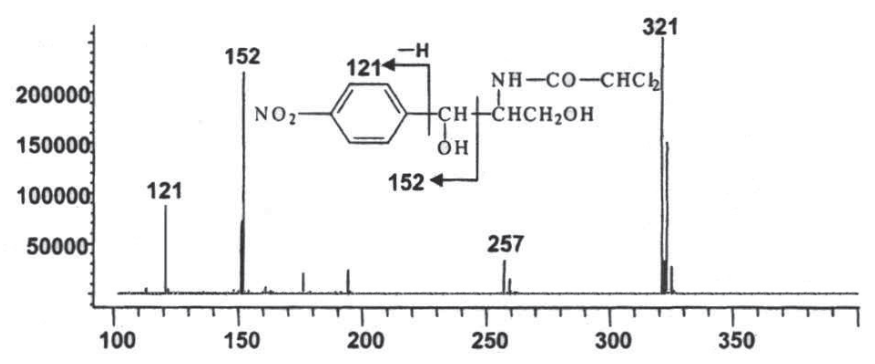

Figure 1. Mass spectrum of CAP and its typical fragmentation pattern.

Table II. Method trueness and precision.

\begin{tabular}{lccc}
\hline $\begin{array}{l}\text { Spike level } \\
(\mu \mathrm{g} / \mathrm{kg})\end{array}$ & Replicates & Mean recovery $(\%)$ & $\begin{array}{c}\text { Relative standard } \\
\text { deviation }(\%)\end{array}$ \\
\hline 0.3 & 6 & 103.6 & 15.0 \\
0.5 & 4 & 100.5 & 14.0 \\
1.0 & 7 & 104.7 & 11.7 \\
\hline
\end{tabular}

Intra-laboratory reproducibility was estimated by analysing multiple replicates of samples for each level of fortification, in different days and by different operators. Method trueness was expressed in terms of recovery rates for CAP and precision as relative standard deviation. Response linearity was evaluated by drawing a 5 points calibration curve in solvent with CAP concentrations corresponding to $0.625,1.25,2.5,5,10 \mu \mathrm{g} / \mathrm{L}$ and containing a fixed amount of 5D-CAP of $12.5 \mu \mathrm{g} / \mathrm{L}$.

\section{RESULTS}

Validation data are reported in Table II. The analysis of chromatograms revealed the absence of interfering peaks at CAP retention time whereas the correlation coefficient for the calibration curve was 0.9996. Calculated LOD (taking into account a signal/noise ratio 3:1 for the most intense transition) was $0.15 \mu \mathrm{g} / \mathrm{kg}$ while the limit of quantification (LOQ) of the method (lowest level at which precision and trueness were evaluated) was $0.3 \mu \mathrm{g} / \mathrm{kg}$.

The number of investigated samples, the minimum, maximum and average concentrations of CAP in royal jelly, expressed as $\mu \mathrm{g} / \mathrm{kg}$, as well as the rates of positive samples arising from both private importers and authorities of Veterinary Border Inspection Posts, are shown in Table III. These data showed that the concentration of CAP ranged from "not detectable" (below $0.3 \mu \mathrm{g} / \mathrm{kg}$ ) to the highest value of $28.0 \mu \mathrm{g} / \mathrm{kg}$. The average CAP content over all the 35 samples was $6.1 \mu \mathrm{g} / \mathrm{kg}$. The rates of positive cases for both private and official samples are summarized in Table III.

In the first group (A-F), 17 out of 21 samples resulted positive for CAP with an overall incidence of $81.0 \%$. The rate of positive cases in officially collected samples (G-I) was also extremely high: 12 out of the 14 controls performed, corresponding to $85.7 \%$, revealed the presence of CAP. In total 29 out of 35 samples tested positive to CAP.

\section{DISCUSSION}

The proposed method was developed for the determination of CAP in royal jelly at a detection limit consistent with the Minimum Required Performance Limit (MRPL) required by the European legislation for CAP (European Commission, 2003). Tandem mass spectrometry using MRM transitions of analytespecific fragment ions enabled a selective and sensitive detection, in agreement with the EU criteria for the confirmatory analysis of banned 
a)
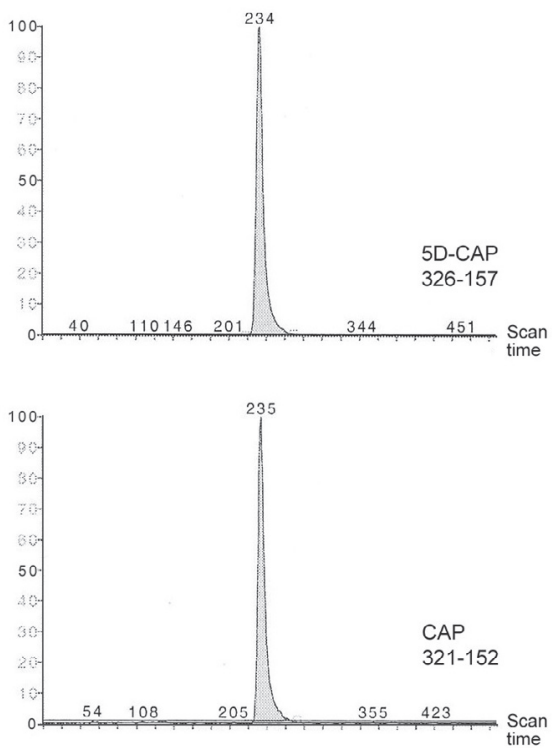

b)
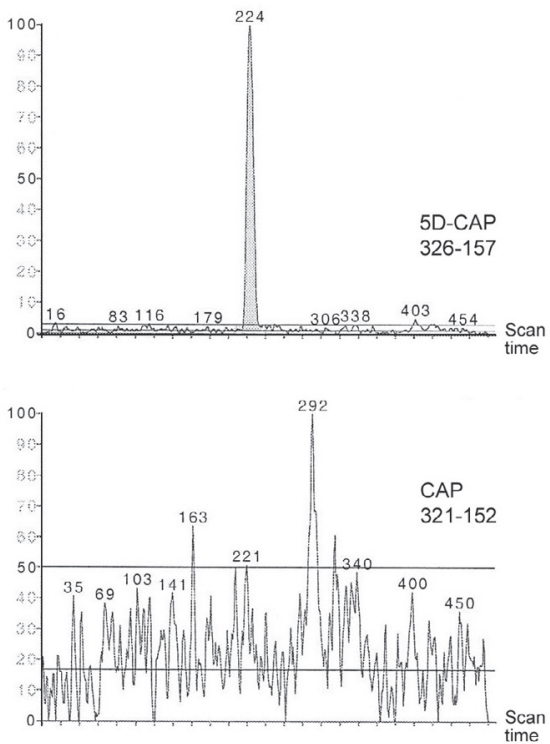

c)
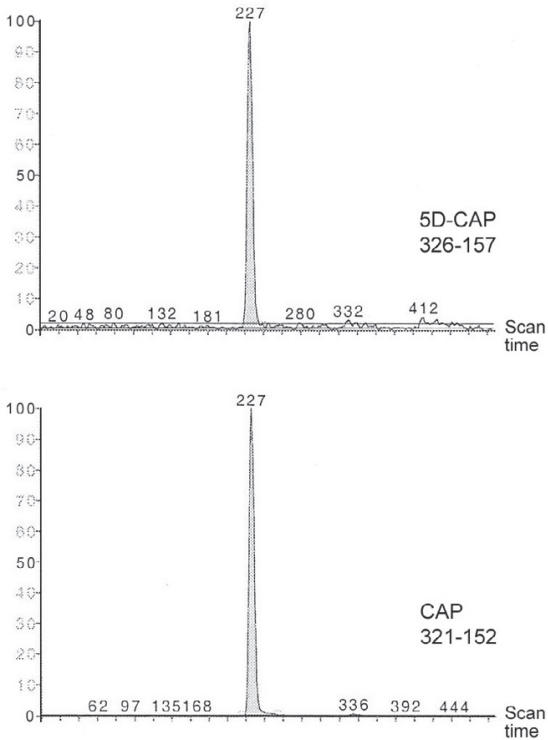

Figure 2. Chromatogram of a standard solution containing 5D-CAP and CAP at the concentration of 12.5 and $2.5 \mu \mathrm{g} / \mathrm{L}$ respectively (a); chromatogram of a sample of royal jelly negative for CAP (b); chromatogram of a sample of royal jelly positive for CAP (c).

substances. Moreover, the choice of isotopelabelled CAP as an internal standard allowed an accurate and precise quantification of the analyte, while the adoption of the adequate clean up procedure made the method suitable for routine analysis of CAP in royal jelly.
From a food safety point of view, since the use of CAP in food-producing animals is banned in the EU countries, USA, Canada and Australia, the high incidence of positive cases is alarming. The presence of this antibiotic in a high percentage of royal jelly samples from 
Table III. CAP concentration in royal jelly samples and rates of positive cases (February 2003-July 2004).

\begin{tabular}{llllll}
\hline $\begin{array}{l}\text { Owner } \\
\text { Firm }\end{array}$ & $\begin{array}{l}\text { Number } \\
\text { of samples }\end{array}$ & $\begin{array}{l}\text { Minimum } \\
(\mu \mathrm{g} / \mathrm{kg})\end{array}$ & $\begin{array}{l}\text { Maximum } \\
(\mu \mathrm{g} / \mathrm{kg})\end{array}$ & $\begin{array}{l}\text { Average } \\
(\mu \mathrm{g} / \mathrm{kg})\end{array}$ & $\begin{array}{l}\text { Positive cases } \\
(\%)\end{array}$ \\
\hline $\mathrm{A}$ & 4 & 8.6 & 28.0 & 16.0 & 100 \\
$\mathrm{~B}$ & 8 & $<0.3$ & 13.7 & 6.3 & 87.5 \\
$\mathrm{C}$ & 3 & $<0.3$ & $<0.3$ & $<0.3$ & 0 \\
$\mathrm{D}$ & 1 & 6.9 & 6.9 & 6.9 & 100 \\
$\mathrm{E}$ & 1 & 0.6 & 0.6 & 0.6 & 100 \\
$\mathrm{~F}$ & 4 & 3.6 & 17.3 & 12.6 & 100 \\
$\mathrm{G}$ & 12 & $<0.3$ & 6.7 & 2.6 & 83.3 \\
$\mathrm{H}$ & 1 & 1.7 & 1.7 & 1.7 & 100 \\
$\mathrm{I}$ & 1 & 7.8 & 7.8 & 7.8 & 100 \\
Total & & & & & 82.8 \\
\hline
\end{tabular}

both private owners and official control samples indicates possible threats to human health from a food consumed with the purpose of health improvement. In particular, apart from the demonstrated toxicity of CAP in humans in general (Allen, 1985; IARC, 1990), it must be stressed that royal jelly is widely consumed by risk groups as children, old people and pregnant or breast-feeding women.

In conclusion, because of the high toxicity of CAP, an intensification of the monitoring activity is advisable both in imported or nationally produced royal jelly to assure better consumers protection.

Résumé - Le chloramphénicol dans la gelée royale : aspects analytiques et présence dans les importations italiennes. Le chloramphénicol (CAP) est un antibiotique à large spectre couramment utilisé dans le traitement de diverses maladies infectieuses. Ces dernières années la contamination par le CAP de la gelée royale importée est devenue un problème sérieux dans le domaine de la sécurité alimentaire. Ce travail décrit la méthode adoptée pour déterminer le CAP (chromatographie en phase liquide couplée à la spectrométrie de masse en tandem) et l'image qui émerge de l'activité de contrôle menée sur 35 échantillons de gelée royale en Italie de février 2003 à juillet 2004. La présence de CAP a été détectée dans $83 \%$ des échantillons à des concentrations comprises entre $0,6 \mu \mathrm{g} / \mathrm{kg}$ et $28 \mu \mathrm{g} / \mathrm{kg}$ (moyenne $6,1 \mu \mathrm{g} / \mathrm{kg}$ ). La situation décrite souligne donc le besoin d'intensifier les activités de contrôle aux niveaux national et international.

gelée royale / résidu / antibiotique / chloramphénicol / chromatographie phase liquide / spectrométrie de masse en tandem
Zusammenfassung - Chloramphenicol in Gelee Royale: Analytische Aspekte und das Vorkommen in italienischen Importen. Chloramphenicol (CAP) ist ein zur Behandlung von verschiedenen Infektionskrankheiten häufig verwendetes Breitbandantibiotikum. In den vergangenen Jahren ist die Verunreinigung von importiertem Gelee Royale mit CAP zu einem ernsten Problem bezüglich der Nahrungsmittelsicherheit geworden. Die vorliegende Arbeit beschreibt die zur Bestimmung von CAP übernommene Methode (Flüssigchromatographie mit MS-Kopplung, LC-MS/MS) und das Ergebnis von in Italien durchgeführten Kontrollen. CAP wurde in $83 \%$ von 35 zwischen Februar 2003 und Juli 2004 erhobenen Proben in Konzentrationen von $0,6 \mu \mathrm{g} / \mathrm{kg}$ bis $28 \mu \mathrm{g} / \mathrm{kg}$ mit einem mittleren Gehalt von $6,1 \mu \mathrm{g} / \mathrm{kg}$ nachgewiesen. Die beschriebene Situation unterstreicht die Notwendigkeit, nationale und internationale Kontrollen zu verstärken.

Gelee Royale / Chloramphenicol / Rückstände / Antibiotika / Flüssigchromatographie mit MSKopplung

\section{REFERENCES}

Allen E.H. (1985) Review of chromatographic methods for chloramphenicol residues in milk, eggs and tissues from food-producing animals, J. Assoc. Off. Anal. Chem. 68, 990-999.

Bogusz M.J., Hassan H., Al-Henazi E., Ibrahim Z., Al-Tufail M. (2004) Rapid determination of chloramphenicol and its glucuronide in food products by liquid chromatography-electrospray negative ionisation tandem mass spectrometry, J. Chromatogr. B 807, 343.

Chen-Sheng L., Su-Song K., Lin-Xue Z. (2002) Dept of sericultural and apicultural sciences, Bee World 83, 69-77. 
European Commission (2003) Commission Decision 2003/181/EC amending Decision $2002 / 657 / \mathrm{EC}$ as regards the setting of minimum required performance limits (MRPLs) for certain residues in food of animal origin, Off. J. Eur. Communities Mar 13th 2003, L 71/17-18. [online] http://europa.eu.int/eurlex/pri/en/oj/dat/2003/1_071/1_07120030315en00170018.pdf (accessed on 2 June 2006).

FSA (Food Standards Agency) (2002) http:// www.food.gov.uk (accessed on 2 June 2006).

Gantverg A., Shishani I., Hoffman M. (2003) Determination of chloramphenicol in animal tissues and urine. Liquid chromatography-tandem mass spectrometry versus gas chromatographymass spectrometry, Anal. Chim. Acta 483, 125.

Hormazabal V., Yndestad M. (2001) Simultaneous determination of chloramphenicol and ketoprofen in meat and milk and chloramphenicol in egg, honey, and urine using liquid chromatography-mass spectrometry, J. Liq. Chromatogr. Relat. Technol. 24, 2477.

IARC (International Agency for Research on Cancer) (1990) Monograph on the evaluation of carcinogenic risk to humans, IARC Press, Lyon, France, 50 .
Mottier P., Parisod V., Gremaud E., Guy P.A., Stadler R.H. (2003) Determination of the antibiotic chloramphenicol in meat and seafood products by liquid chromatography-electrospray ionisation tandem mass spectrometry, J. Chromatogr. A 994, 75.

Ramos M., Muñoz P., Aranda A., Rodriguez I., Diaz R., Blanca J. (2003) Determination of chloramphenicol residues in shrimps by liquid chromatography-mass spectrometry, J. Chromatogr. B 791, 31 .

RASFF (Rapid Alert System for Food and Feed) (2002-2004) Annual Report on the Functioning of the RASFF, http://europa.eu.int/comm/food/food/rapidalert/ index_en.htm (accessed on 2 June 2006).

Verzegnassi L., Royer D., Mottier P., Stadler R.H. (2003) Analysis of chloramphenicol in honeys of different geographical origin by liquid chromatography coupled to electrospray ionisation tandem mass spectrometry, Food Addit. Contam. 20, 335.

WHO (1994) Toxicological evaluation of certain veterinary drug residues in food, Food Addit. Series N. 33.

WHO (1995) Evaluation of certain veterinary drug residues in food, Tech. Rep. Series N. 851. 